\title{
PERSPEKTIF POLITIK HUKUM DAN TEORI HUKUM PEMBANGUNAN TERHADAP TANGGUNG JAWAB SOSIAL DAN LINGKUNGAN PERSEROAN TERBATAS
}

\author{
Wiman Wibisana \\ Kandidat Doktor Ilmu Hukum Fakultas Hukum \\ Universitas Gadjah Mada Yogyakarta \\ Senior Legal Advisor ABC Law Bali \\ Email : wiman@abclaw.id
}

\begin{abstract}
ABSTRAK
Ketentuan Pasal 74 Undang-Undang Nomor 40 Tahun 2007 tentang Perseroan Terbatas yang mewajibkan Perseroan Terbatas khususnya yang bergerak dalam bidang Sumber Daya Alam untuk menyalurkan Tanggung Jawab Sosial dan Lingkungan atau secara luas dikenal sebagai Corporate Social Responsibility, merupakan sebuah hal baru yang menimbulkan perdebatan. Pada satu sisi Perusahaan sebagai entitas bisnis bertujuan untuk menghasilkan laba yang sebesar-besarnya, namun pada sisi lain sebagai entitas yang ada di tengah-tengah masyarakat Perusahaan pun harus memperhatikan kondisi sekelilingnya. Perkembangan ajaran mengenai tata kelola perusahaan yang baik atau good corporate governance yang salah satu prinsip pokoknya adalah tanggung jawab, kemudian memberikan pengaruh mengenai tujuan perusahaan itu sendiri. Pola perusahaan yang mengejar sebesar-besarnya keuntungan perlahan bergeser menjadi perusahaan yang bertanggung jawab terhadap usahanya dalam mengejar profit. Ditinjau dari perspektif Politik Hukum, aturan mengenai kewajiban Perusahaan menyalurkan Tanggung Jawab Sosial dan Lingkungan merupakan sebuah upaya pembuat aturan untuk mewujudkan cita-cita hukumnya atau dalam teori hukum pembangunan dimaknai sebagai sebuah social engineering untuk mewujudkan perusahaan yang baik.
\end{abstract}

Keyword: CSR, GCG, Teori Hukum Pembangunan.

\begin{abstract}
The provision of Article 74 of Law Number 40 Year 2007 concerning Limited Liability Companies which requires Limited Liability Company, especially those engaged in Natural Resource to distribute Social and Environmental Responsibility or widely known as Corporate Social Responsibility, is a novelty that raises the debate. On the one hand, the Company as a business entity aims to generate profits as much as possible, but on the other hand as an entity in the midst of society Company must also pay attention to the conditions surrounding. The development of the doctrine of good corporate governance, which is one of the main principles is the responsibility, then gives influence on the purpose of the company itself. The pattern of companies that pursue profitable profits slowly shifted into a company that is responsible for his efforts in the pursuit of
\end{abstract}


profit. Judging from the perspective of Political Law, the rules regarding the Company's obligations to channel Social and Environmental Responsibility is an attempt by the regulators to realize their legal ideals or in development law theory is interpreted as a social engineering to create a good company.

Keyword: CSR, GCG, Theory of Development Law,

\section{Pendahuluan}

Perkembangan kegiatan ekonomi khususnya dalam bidang penanaman modal mengakibatkan banyaknya kegiatan ekonomi yang tidak cukup hanya dijalankan oleh orang perorang melainkan oleh persekutuan modal. Persekutuan modal yang kemudian bertransformasi menjadi sebuah badan hukum yang memiliki entitas sebagai pemangku hak dan kewajiban yang mandiri melahirkan berbagai perkembangan dalam dunia usaha. Kekuatan korporasi atau entitas usaha dalam beberapa kasus bahkan melampaui kekuatan atau kemampuan negara. Perkembangan ini kemudian melahirkan kekhawatiran tersendiri dari masyarakat dan Negara sehingga menjadi salah satu pendorong regulasi mengenai pentingnya korporasi yang peduli pada lingkungan dan tumbuh secara berkesinambungan (sustainable).

Pada tataran global, muncul inisiatif gerakan Corporate Social Responsibility atau lazim dikenal dengan istilah CSR, yang menititkberatkan bahwa perusahaan atau korporasi memiliki tanggung jawab social dan lingkungan dalam menjalankan usahanya. Pemaknaan tanggung jawab korporasi dalam hal ini mencakup cakupan yang luas dan ditafsirkan secara berbeda diberbagai belahan dunia. Ahli dari Negara-negara yang corak system ekonominya dipengaruh oleh Kapitalisme, menganggap CSR merupakan hal yang tidak diperlukan karena korporasi telah membayar kewajibannya melalui system perpajakan, Milton Friedman adalah salah satu penganjur pendapat ini, menurutnya satu-satunya tanggungjawab sosial korporasi adalah meningkatkan keuntungan pemegang saham sebagai tugas perintah moral (Milton Friedman;1970).

Menurut Friedmann, CSR merupakan bentuk kewajiban yang tidak diperlukan karena hanya menambah beban keuangan korporasi yang pada akhirnya akan mengurangi keuntungan para pemegang saham. Friedman berpandangan bahwa pajak perusahaan yang telah dibayarkan merupakan sebuah bentuk tanggung jawab korporasi kepada para stakeholdernya.

Sebaliknya di kutub lain di Negara-negara berkembang yang menjadi sasaran industrialisasi, CSR dianggap perlu sebagai wujud nyata upaya menyeimbangkan kepentingan stakeholder dan sekaligus juga upaya untuk mengendalikan korporasi agar 
sejalan dengan ide kelestarian lingkungan. Indonesia sebagai Negara yang diakui memiliki kekayaan alam yang melimpah sejak era penjajahan hingga era kemerdekaan memiliki cara pandang tersendiri terhadap bagaimana CSR yang diistilahkan dalam Bahasa regulasi Indonesia khususnya Undang-Undang Perseroan Terbatas Nomor 40 Tahun 2007 sebagai Tanggung Jawab Sosial dan Lingkungan .

Implikasi gramatikal dari penyerapan istilah ini menghasilkan paradigma bahwa tujuan tanggung jawab social perusahaan tidak hanya bertujuan sosial namun juga memiliki aspek lingkungan di dalamnya. Lebih lanjut jika ditelaah dari struktur tata kelola usaha yang baik atau Good Corporate Governance yang menjadi ciri dan acuan pengelolaan korporasi modern, nilai responsibility atau tanggung jawab merupakan salah satu komponen penting dari empat pilar Good Corporate Governance yang terdiri dari Fairness ( Keadilan), Accountability ( Akuntabilitas), Transparancy (Keterbukaan ) dan Responsibility ( tanggung jawab) (Bismar Nasution, 2003).

Perkembangan pengaturan CSR dalam hukum positif yang ditandai dengan pengaturan secara khusus bagi Perseroan Terbatas dalam Pasal 74 Undang-Undang Nomor 40 Tahun 2007, menunjukkan adanya perubahan paradigma politik hukum Negara terhadap arah perkembangan hukum perusahaan. Hal ini tercermin jika dikomparasikan antara Undang-Undang Nomor 40 Tahun 2007 tentang Perseroan Terbatas secara vis a vis dengan Undang-Undang Nomor 1 Tahun 1995 tentang Perseroan Terbatas yang merupakan sebuah Ketentuan Hukum mengenai Perseroan Terbatas yang murni dibuat bangsa Indonesia setelah sebelumnya menggunakan rumusan Wetboek van Kophandel atau Kitab UndangUndang Hukum Dagang yang merupakan warisan pemerintah kolonial.

Politik Hukum sendiri dalam pemaknaan Teuku Mohammad Radhie dimaknai sebagai suatu pernyataan kehendak penguasa negara mengenai hukum yang berlaku di wilayahnya dan mengenai arah hukum, perkembangan hukum yang dibangun (Mahfud MD, 2009). Jika dikaitkan dengan Teori Hukum Pembangunan yang digagas oleh Mochtar Kusumaatmadja yang terinspirasi dari Roscoe Pound, yang menitikberatkan dua unsur penting dari tujuan hukum yakni sebagai alat kontrol sosial (tool of social control) dan sebagai alat untuk rekayasa sosial (tool of social engineering).

Mochtar

Kusumahatmadja berpendapat :

Hukum merupakan suatu alat untuk memelihara ketertiban dalam masyarakat.mengingat fungsinya, sifat hukum pada dasarnya adalah konservatif artinya hukum memelihara dan mempertahankan apa yang telah tercapai. Fungsi demikian diperlukan dalam setiap masyarakat termasuk masyarakat yang sedang 
membangun, karena disini pun ada hasil-hasil yang harus dipelihara, dilindungi dan diamankan. Akan tetapi masyarakat yang sedang membangun, dalam definisi kita berarti masyarakat yang sedang berubah cepat, hukum tidak cukup memiliki fungsi demikian saja. Ia juga harus mampu membantu proses perubahan masyarakat itu. Pandangan yang kolot tentang hukum yang menitikberatkan fungsi pemeliharaan ketertiban dalam arti statis dan menekankan sifat konservatif dari hukum, menganggap bahwa hukum tidak dapat memainkan suatu peranan yang berarti dalam proses pembaharuan. Ucapan bahwa dengan ahli hukum orang tidak dapat membuat revolusi menggambarkan demikian.

Anggapan tadi tidak benar dan dibantah antara lain oleh pengalaman di Amerika Serikat. Di negara ini terutama setelah dilaksanakannya New Deal mulai tahun tigapuluhan kita telah menyaksikan dipergunakannya hukum sebagai alat untuk mewujudkan perubahan di bidang sosial. Di negara inilah timbul istilah law as a tool of social engineering ( $R$ Pound) (Kusumahatmadja, 2006).

Maka nampak upaya pembangunan hukum perseroan ke arah tata kelola usaha yang baik melalui kemunculan UndangUndang Nomor 40 Tahun 2007 yang menginisiasi beberapa hal baru yang dipengaruhi oleh konsep tata kelola yang baik salah satunya adalah tanggung jawab sosial dan lingkungan Perseroan Terbatas. Jika arah politik hukum perseroan yang terkandung dalam Wetboek van Kophandel adalah arah politik hukum kolonial, dan Politik Hukum dalam Undang-Undang Nomor 1 Tahun 1995 adalah Politik Hukum Orde Baru, maka dengan diintrodusirnya Undang-Undang Nomor 40 Tahun 2007 yang menggantikan Undang-Undang Nomor 1 Tahun 1995, Hukum Perseroan terbatas memiliki arah politik hukum baru pasca reformasi.

Secara filosofis, perubahan regulasi ini tidak semata-mata dimaknai sebagai sebuah upaya teknis peruabahan peraturan, melainkan perlu ditelaah hal apa yang mendasari perubahan regulasi ini. Von Savigny berpendapat bahwa " Das Recht wird nicht gemacht, est ist und wird mit dem volke"- Hukum itu tidak dibuat, tetapi tumbuh dan berkembang bersama masyarakat, lebih jauh Von Savigny berpendapat bahwa pada setiap bangsa terdapat volkgeist atu jiwa bangsa yang mempengaruhi isi hukum dari suatu bangsa sebagai akibat dari pergaulan manusia dari masa ke masa (Rasjidi \& Ira Thania Rasjidi, 2007;63).

Maka patut ditelaah dan dikaji lebih jauh apakah perubahan regulasi terkait dengan Perseroan Terbatas ini adalah akibat adanya perubahan pengaruh politik hukum atau sebab lainnya. Hal ini mengingat bahwa hukum Hukum perusahaan sendiri berasal dari perkembangan hukum dagang 
yang berasal dari hukum yang dibuat oleh para pedagang (gilda) yang dalam transaksinya hukum perdata yang ada dirasa tidak mampu menyelesaikan permasalahan yang dihadapi (Masriani, 2004;104).

\section{Rumusan Masalah :}

1. Bagaimanakah Regulasi CSR ditinjau dari Perspektif Politik Hukum Perusahaan terkait dengan Tata Kelola Usaha Yang Baik?

2. Bagaimanakah pengaruh Teori Hukum Pembangunan dalam Regulasi CSR di Indonesia?

\section{Pembahasan}

Politik Hukum UU Nomor 40 Tahun 2007 tentang Perseroan Terbatas

Perkembangan perekonomian Indonesia dan perubahan dinamika kehidupan masyarakat Indonesia sejak kemerdekaan mengalami pertumbuhan yang pesat. Hal ini kemudian mengantarkan Masyarakat Indonesia pada kebutuhan akan hukum yang mengakomodir kepentingannya yang dinamis. Menurut CFG Sunaryati Hartono, baik teori maupun praktik hukum telah menjelaskan bahwa hukum memang mempunyai peranan yang penting, khususnya menjaga keseimbangan, keselarasan dan keserasian diantara berbagai kepentingan di dalam masyarakat (Hartono;1991).

Lebih jauh diungkapkan bahwa seiring tuntutan dalam perekonomian yang perlu dipertimbangkan untuk dibenahi adalah Hukum Kontrak dan Hukum Perusahaan. Tentunya aspek yang harus dipertimbangkan dalam perubahan ini tidak semata dari aspek hukum atau ekonomi semata namun seyogianya didasarkan pada penalaran dan pertimbangan politik ekonomi pembangunan yang dipadukan dengan politik hukum pembangunan maupun pertimbangan politik pembangunan sodial masyarakat secara intern dan transdisipliner secara holistik/ sistematik.

Dalam perjalanannya, UndangUndang Nomor 40 Tahun 2007 tentang Perseroan Terbatas lahir menggantikan Undang-Undang Nomor 1 Tahun 1995 tentang Perseroan Terbatas didasari oleh pemikiran berikut : Pertama, Undang-Undang lama dirasa sudah tidak memadai dalam menampung perkembangan hukum dan dinamika masyarakat. Kedua, Undang-Undang baru diharapkan menciptakan iklim usaha dan perdagangan yang lebih sehat dan dinamis. Ketiga, meningkatkan minat Investor asing untuk berinvestasi (Haryanto, 2007).

Selain itu pemikiran berikutnya adalah dengan lahirnya beberapa undang-undang baru diperlukan penyederhanaan dan penyempurnaan prosedur pengesahan dan permohonan perseroan terbatas. Kelima, dimaksudkan untuk mendukung pelaksanaan Good Corporate Governance dan Keenam, karena Rancangan Undang-Undang ini merupakan prioritas yang telah disepakati oleh Presiden dan DPR. 
Selain itu, dalam Laporan Ketua Panitia Khusus RUU Perseroan Terbatas, M Akil Mochtar, mengungkapkan bahwa perubahan Undang-Undang dimaksudkan untuk menyempurnakan ketentuan Undang-Undang Nomor 1 Tahun 1995 tentang Perseroan Terbatas khususnya tuntuan agar perkembangan dunia usaha disesuaikan dengan prinsip tata kelola usaha yang baik. Sedangkan ketentuan mengenai CSR dimaksudkan untuk mendukungterjalinnya hubungan perseroan yang selaras, serasi dan seimbang, dan sesuai dengan lingkungan, nilai, norma dan budaya masyarakat setempat. Keseluruhan Fraksi yang ada di Dewan Perwakilan Rakyat pun, memiliki pendapat yang seragam yang mendorong upaya legislasi CSR ke dalam Undang-Undang Perseroan Terbatas.

Mengacu pada dasar pemikiran tersebut nampak jelas ada keinginan dari pemangku kepentingan untuk menerapkan prinsip-prinsip tata kelola usaha yang baik atau Good Corporate Governance dalam Undang-Undang Perseroan Terbatas. Mengacu pada pendapat Teuku Mohammad Radhie yang memaknai politik hukum sebagai suatu pernyataan kehendak penguasa negara mengenai hukum yang berlaku di wilayahnya dan mengenai arah hukum, perkembangan hukum yang dibangun. Maka dalam hal ini nampak arah politik hukum Indonesia dalam hukum perusahaan mengarah kepada penerapan prinsip tata kelola usaha yang baik, yang salah satunya dicerminkan dari legislasi norma mengenai CSR ke dalam UndangUndang.

Salah satu perubahan yang cukup fundamental dalam UndangUndang Nomor 40 Tahun 2007 tentang Perseroan Terbatas adalah adanya Tanggung Jawab Sosial dan Lingkungan (TJSL) atau Corporate Social Responsibility (CSR) yang menjadikan tujuan pendirian suatu perseroan terbatas tidak sematamata sebagai sebuah kongsi untuk meraih keuntungan melainkan juga harus membawa manfaat bagi pemangku kepentingan yang terkait dengan aktivitas perusahaan. Perseroan Terbatas yang diwajibkan mengeluarkan dana untuk CSR adalah Perseroan Terbatas yang bergerak dalam bidang sumber daya alam (Pasal 74 Undang-Undang Nomor 40 Tahun 2007 tentang Perseroan Terbatas). Kendatipun demikian dalam Peraturan Pemerintah Nomor 47 Tahun 2012 yang merupakan Peraturan Pemerintah yang ditujukan untuk meregulasi Tanggung Jawab Sosial dan Lingkungan sebagaimana amanat Pasal 74 Undang-Undang Nomor 40 Tahun 2007 tentang Perseroan Terbatas tersebut, Perseroan yang usahanya tidak bergerak dalam bidang sumber daya alam pun dibolehkan untuk mengeluarkan CSR.

Pelaksanaan TJSL atau CSR merupakan hal yang baru yang muncul akibat adanya pandangan moral bahwa Perseroan Terbatas tidak dapat dilepaskan dari 
komunitas yang ada di sekitarnya sehingga Perseroan Terbatas Juga memiliki tanggung jawab untuk mensejahterakan komunitas yang ada di sekitarnya selain tentu tujuan utama Perseroan Terbatas adalah untuk mendapatkan keuntungan yang sebesarbesarnya. Pengaturan mengenai TJSL dalam UU Nomor 40 Tahun 2007 sendiri masih menyisakan beberapa celah dalam penerapannya. Selain itu secara normatif juga dapat ditelaah bagaimana prosedur penyaluran atau pelaksanaan dari TJSL ini, karena pada dasarnya TJSL lahir karena adanya kesadaran dari pelaku usaha dan dunia usaha untuk menjalin hubungan yang saling menguntungkan dengan para pemangku kepentingan yang ada.

CSR sendiri lahir dari prinsip Good Corporate Governance (GCG) yang merupakan prinsip tata kelola perusahaan yang baik. Prinsip tata kelola yang baik ini mencakup empat hal yakni, fairness atau keadilan, transparancy atau keterbukaan, accountabiity atau akuntabilitas, dan responsibility atau tanggung jawab. Titik tekan CSR adalah responsibility atau tanggung jawab.

Lawrence dkk menerjemahkan konsep CSR sebagai " a corporation should be held accountable for any of its action that affect people, their communities and their environment" (Lawrence, et al, 2005). Terjemahan bebasnya adalah korporasi harus bertindak akuntabel atas setiap tindakannya yang mempengaruhi orang, komunitasnya dan lingkungannya.

The Organization for Economic Cooperation and Development (OECD) merumuskan tanggung jawab sosial perusahaan sebagai "business contribution to sustainable development and that corporate behavior must not only ensure returns to shareholders, wages to employees, and products and service to consumers, but they must respond to societal and environmental concerns and value". Definisi OECD ini menekankan bahwa tujuan sebuah bisnis bukan hanya untuk memastikan keuntungan bagi pemegang saham, gaji bagi karyawan, produk dan jasa bagi konsumen, namun harus juga diarahkan untuk perkembangan secara berkelanjutan dengan tanggap terhadap nilai-nilai sosial dan lingkungan.

Perkembangan CSR yang ada saat ini tidak bisa dilepaskan dari pemikiran Howard R. Bowen. Bowen melalui bukunya Social Responsibilities of Businessman merumuskan bahwa "the obligations of businessman to pursue those policies, to make those decision or to follow those lines of action which are desirable in term of the objectives and values of our society". Ide Bowen inilah yang kemudian berkembang menjadi konsep CSR yang ada hingga saat ini. Perkembangan konsep CSR sendiri berkembang dari CSR sebagai sebuah amal atau charity yang dikeluarkan atas dasar kemanusiaan (filantropi) pada era 1950-1960, menjadi stewardship principle atau prinsip yang 
menyatakan bahwa seorang manajer perusahaan adalah wali publik yang mengendalikan sumber daya yang demikian besar yang mana penggunaan sumber daya tersebut menimbulkan dampak bagi beberapa pihak.

Pada dekade 1970-an kemudian stewardship principle berkembang menjadi stakeholder management. Dalam konsep stakeholder management titik tekannya ada pada pemangku kepentingan yang ada di sekitar perusahaan. Jones mendefinisikan stakeholder menjadi dua kategori yakni inside stakeholder dan outside stakeholder. Inside stakeholder atau pemangku kepentingan di dalam perusahaan meliputi pemegang saham, manajer, dan karyawan. Sedangkan outside stakeholder meliputi seluruh pihak di luar perusahaan yang memiliki kepentingan terhadap perusahaan atau dipengaruhi oleh keputusan serta tindakan yang dilakukan perusahaan.

Era 1980-an hingga saat ini, yang dipengaruhi dengan semakin menguatnya pengaruh korporasi sebagai sebuah entitas. Arah CSR pun memuat beberapa komponenkomponen yang terkait erat dengan tanggung jawab perusahaan. Komponen tersebut terdiri dari tanggung jawab ekonomi, tanggung jawab hukum, tanggung jawab etik dan tanggung jawab kepada warga masyarakat di sekelilingnya.

Tanggung jawab ekonomi menitikberatkan tanggung jawab untuk memproduksi barang dan atau jasa yang menguntungkan bagi masyarakat. Dari segi tanggung jawab hukum, operasional sebuah perusahaan haruslah mematuhi berbagai macam regulasi dan ketentuan yang ada yang terkait dengan operasional perusahaan. Tanggung jawab etis merupakan tanggung jawab untuk mejalankan bisnis secara etis sesuai dengan nilai-nilai yang ada dalam masyarakat tempat beroperasinya perusahaan. Komponen terakhir dalam CSR periode ini adalah tanggung jawab kepada warga di sekelilingnya atau corporate citizenship.

Komponen-komponen

tersebut yang dominan dijadikan tolak ukur untuk penyaluran CSR adalah komponen tanggung jawab kepada warga yang ada di sekitar perusahaan. Hal ini dinilai dari program-program yang dirancang korporasi untuk kesejahteraan masyarakat yang ada di sekelilingnya sebagaimana prinsipprinsip pembangunan dan berwawasan lingkungan yang lahir dalam Deklarasi Stockholm 1972, dan kemudian dikembangkan ke dalam prinsip sustainable development (Pembangunan berkelanjutan) (Simorangkir \& Ninuk Arifah;2009).

\section{Teori Hukum Pembangunan dalam Politik Hukum Indonesia}

Soedikno Mertokusumo berpendapat bahwa Teori Hukum adalah Teorinya ilmu hukum. Dengan perkataan lain Ilmu Hukum adalah objek dari Teori Hukum (Sudikno;2015). Menurutnya Teori Hukum berhubungan dengan 
hukum pada umumnya, bukan mengenai hukum di suatu tempat dan di suatu waktu seperti halnya ilmu hukum. Bruggink berpendapat bahwa Teori Hukum adalah keseluruhan pernyataan yang saling berkaitan berkenaan dengan sistem konseptual aturan-aturan hukum dan putusan-putusan hukum dan sistem tersebut untuk sebagian yang penting dipositifkan (Bruggink;2015). Pendapat Bruggink ini mengibaratkan konsep Teori Hukum sebagai produk dan sebagai suatu proses.

Teori Hukum Pembangunan merupakan Teori hukum yang diintrodusir oleh Mochtar Kusumaatmadja, disandarkan pada beberapa prinsip berikut yakni : (1) Semua masyarakat yang sedang membangun selalu dicirikan oleh perubahan dan hukum berfungsi agar menjamin bahwa perubahan itu terjadi dengan cara yang teratur. (2) Baik Perubahan maupun ketertiban merupakan tujuan awal dari masyarakat yang sedang membangun maka hukum menjadi suatu sarana yang tidak dapat diabaikan dalam proses pembangunan. (3) Fungsi Hukum dalam masyarakat adalah mempertahankan ketertiban melalui kepastian hukum dan juga hukum sebagai kaidah sosial harus dapat mengatur proses perubahan dalam masyarakat. (4) Hukum yang baik adalah hukum yang sesuai dengan hukum yang hidup dalam masyarakat. (5) Implementasi fungsi hukum tersebut hanya dapat diwujudkan jika hukum dijalankan oleh kekuasaan, tetapi kekuasaan itu sendiri harus berjalan dalam batas rambu-rambu yang ditentukan di dalam hukum itu (Romli Atmasasmita).

Dalam Kata Pengantar Buku "Teori Hukum Integratif Rekonstruksi Terhadap Teori Hukum Pembangunan dan Teori Hukum Progresif" karya Romli Atmasasmita, Lili Rasjidi mengemukakan bahwa Teori Hukum Pembangunan yang digagas Mochtar Kusumaatmadja mengembangkan 3 hal baru yakni konsep hukum baru, hukum sebagai sarana pembaruan masyarakat, dan bahwa hukum ada yang bersifat netral dan tidak netral. Konsep baru ini menyatakan bahwa hukum bukan semata-mata kaidah/norma dan asas melainkan pula gejala sosial budaya. Hukum juga dapat menjadi sarana untuk pembaharuan masyarakat sebagaimana pemikiran yang dikembangkan Roscoe Pound "Law as a tool of social engineering". Netralitas hukum sendiri dimaknai sebagai Hukum yang netral adalah hukum yang tidak ada kaitannya sama sekali dengan faktor kepercayaan, keyakinan dan budaya masyarakat setempat. Hukum yang netral ini dapat dibuat bilamana diperlukan dan berbeda dengan hukum yang bersifat tidak netral seperti hukum waris, keluarga dan lain-lain.

Menurut Romli Atmasasmita, Teori Hukum Pembangunan merupakan Teori yang telah dimasukkan sebagai materi hukum dalam Pembangunan Lima Tahun (Pelita) I (1970-1975). Namun Teori Hukum Pembangunan tidak dicantumkan lagi dalam Rencana 
Pembangunan Jangka Menengah dan Rencana Pembangunan Jangka Panjang Nasional Tahun 20092014. Namun pendapat ini sedikit kurang tepat karena jika ditelaah lebih mendalam, Teori Hukum Pembangunan justru diintrodusir secara tegas dalam Rencana Pembangunan Lima Tahun II.

Hal ini dapat dilihat dari penegasan konsep "Law as a tool of social engineering" yang secara tegas diadopsi dalam Rencana Pembangunan Lima Tahun ke II dimana dalam Bab 27 Buku III dari halaman 313 hingga 330 dijabarkan secara menyeluruh arah politik hukum pemerintah yang berbunyi :

Hukum sebagai sarana menunjang perkembangan modernisasi dan pembangunan yang menyeluruh mencakup segenap bidang pembangunan sehingga untuk melaksanakan fungsinya secara efisien dan produktif, perlu pembinaan hukum itu dikaitkan secara langsung dengan berbagai kebijaksanaan di segenap bidang pembangunan agar kerangka hukumnya dapat dimintakan sebagai pemberi patokan serta pengarahan selanjutnya bagi pembangunan ekonomi dan perkembangan sosial budaya.

Lebih jauh Romli berpendapat bahwa Teori Hukum Pembangunan yang tidak dicantumkan lagi dalam RPJM-RPJP 2004-2009, karena RPJM-RPJP tersebut mengadopsi Model Sistem Hukum menurut Friedman. Friedman mengatakan bahwa hukum sebagai suatu sistem merupakan subjek dari ilmu sosial, bukan ilmu sosial yang independen. Friedman memang membagi komponen Sistem Hukum menjadi Substansi Hukum, Struktur hukum, dan budaya hukum sebagai bagian integral dari suatu sistem hukum.

Jika ditinjau dari aspek formal semata mengenai adopsi ide-ide ke dalam naskah formal, memang RPJP-RPJM 2004-2009 yang menjadi Politik Hukum Pemerintah 2004-2009 memang nampak mengadopsi pemikiran Friedman dan tidak mengadopsi Teori Hukum Pembangunan. Namun jika ditinjau lebih dalam, inti dari arah pembangunan hukum yang mengadopsi model Friedman dalam RPJPM ini tidak bisa dilepaskan dari Pemikiran Teori Hukum Pembangunan yang berupaya menjadikan hukum sebagai sarana mengarahkan pembangunan.

Sebagai contoh nyata adalah pada bagian Arah Kebijakan dalam RPJPM mencantumkan bahwa arah kebijakan akan diarahkan pada :

"Menata kembali substansi hukum melalui peninjauan dan penataan kembali peraturan perundang-undangan untuk mewujudkan tertib perundangundangan dengan memperhatikan asas umum dan hirarki perundang-undangan; dan menghormati serta memperkuat kearifan lokal dan hukum adat untuk memperkaya sistem hukum dan peraturan melalui pemberdayaan yurisprudensi sebagai bagian dari upaya pembaruan materi hukum nasional". (Peraturan 
Presiden Republik Indonesia Nomor 7 tahun 2005 tentang Rencana Pembangunan Jangka Menengah Nasional 20042009).

Mengacu pada deskripsi tersebut, nampak bahwa kendatipun menggunakan model pemikiran Friedman dengan mengurai sistem hukum menjadi Substansi, Struktur, dan Budaya, arah politik hukum kita masih diwarnai oleh ide Teori Hukum Pembangunan yang menjadikan hukum sebaga sarana perubahan sosial. Hal ini didasari oleh upaya menghormati dan memperkuat kearifan lokal dan hukum adat untuk memperkaya sistem hukum dan peraturan.

Arah memperkuat kearifan lokal dan hukum adat ini kemudian diterjemahkan dalam lapangan hukum perusahaan menjadi tanggung jawab sosial dan lingkungan perusahaan. Hal ini didasari bahwa dalam Wetboek van Kophandel atau Kitab UndangUndang Hukum Dagang maupun dalam Undang-Undang Nomor 1 Tahun 1995 tentang Perseroan Terbatas, secara filosofis tujuan perusahaan adalah meraih keuntungan seoptimal mungkin tanpa mengaitkan dengan tata kelola usaha yang baik dan tanggung jawab sosial perseroan yang bisa ditinjau dari tidak adanya klausul atau ketentuan yang mengharuskan perusahaan bertanggung jawab secara sosial.

Arah politik hukum ini kemudian diperjelas melalui Pendapat akhir Pemerintah terhadap Pemandangan umum
Fraksi-Fraksi di Dewan Perwakilan Rakyat yang salah satu pandangannya diwarnai harapan agar undang-undang Nomor 40 Tahun 2007 juga mempunyai makna "Menjamin terselenggaranya usaha Perseroan secara bertanggung jawab dalam hubungan sosialnya maupun lingkungannya sehingga tercipta hubungan yang harmonis dalam komunitas dunia usaha dan keberlangsungan usaha suatu perseroan dalam mencapai tujuan perseroan.

\section{Perkembangan Penerapan Tata Kelola Usaha Yang Baik di Indonesia}

Menurut Robert P. Maxon, konsep dari corporate governance adalah mengenai memaksimalkan nilai dari pemegang saham secara legal, beretika dan berkesinambungan, di samping memastikan keadilan bagi setiap pemegang pancang perusahaan konsumen perusahaan, pegawai, investor, vendor-partners, pemerintah setempat dan komunitas lainnya. Oleh sebab itu, corporate governance adalah sebuah refleksi dari kultur perusahaan, kebijakankebijaknnya, bagaimana mereka memperlakukan pemegang pancangnya dan komitmen mereka dengan nilai-nilai yang dipegangnya (Wiman;2012).

Secara umum Corporate governance didefiniskan sebagai suatu rangkaian proses, kebiasaan, kebijakan, hukum dan institusi yang mampu mempengaruhi bagaimana sebuah perusahaan 
diarahkan, dikelola ataupun dikendalikan. Corporate governance juga meliputi hubungan di antara stakeholder yang terlibat dan tujuan-tujuan yang ingin dicapai sebuah perusahaan. Stakeholder yang utama adalah pemegang saham, manajemen dan dewan direksi. Pemegang pancang lain termasuk di dalamnya pegawai, suplier, konsumen, bank dan lender yang lain, regulator, lingkungan sekitar dan komunitas luas lainnya.

Secara historis corporate governance tak dapat dilepaskan dari Bank of England dan London Stock Exchange pada tahun 1992 yang berusaha melembagakan corporate governance dengan membentuk Cadbury Committee yang bertujuan menyusun corporate governance code yang menjadi acuan utama (benchmark) di banyak negara (Surya \& Ivan Yustiavandana, 2008). Komite Cadburry mendefinisikan corporate governance sebagai sistem yang mengarahkan dan mengendalikan perusahaan dengan tujuan, agar mencapai keseimbangan antara kekuatan kewenangan yang diperlukan oleh perusahaan untuk menjamin kelangsungan eksistensinya dan pertanggungjawaban kepada stakeholders. Hal ini berkaitan dengan peraturan kewenangan pemilik, Direktur, Manajer, pemegang saham, dan sebagainya (Cadburry, 1992).

Price Waterhouse Coopers mendefinisikan corporate governance terkait dengan pengambilan keputusan yang efektif. Dibangun melalui kultur organisasi, nilai-nilai, sistem, berbagai proses, kebijakankebijakan dan struktur organisasi, yang bertujuan untuk mencapai bisnis yang menguntungkan, efisien dan efektif, dalam mengelola risiko dan bertanggungjawab dengan memperhatikan kepentingan stakeholders. Center for European Policy Studies (CEPS) mendefinisikan Good Corporate Governance sebagai seluruh sistem yang dibentuk mulai hak (rights), proses dan pengendalian baik yang ada didalam maupun di luar manajemen perusahaan (Adrian Sutedi, 2011).

Ditinjau dari perspektif definisi maka tata kelola perusahaan yang baik tidak dapat dilepaskan dari relasi perusahaan dengan pemangku kepentingan yang ada disekitarnya. Tata kelola yang baik dari suatu perusahaan mengacu pada panduan yang dikeluarkan Organisation for Economic Cooperation and Development, mencakup beberapa hal yakni Ensuring the Basis for an effective corporate governance framework, rights of shareholder and key ownership function, Equitable treatment of Shareholder, role fo stakeholders in corporate governance, disclosure and trasnparency, dan responsibility of the board (Organization for Economic Co-operation and Development , 2004).

Ensuring the basis for an effective corporate governance framework, merupakan prinsip pertama dalam pedoman yang 
dikeluarkan OECD dalam tata kelola perusahaan. Kerangka kerja perusahaan yang jadi pemikiran utama dalam poin ini adalah agar kerangka kerja perusahaan senantiasa mengedepankan pasar yang transparan dan efisien, konsisten dengan hukum yang berlaku, dan bertanggung jawab pada setiap pengawasan, peraturan dan penegakan peraturan. Titik tekan pemikiran butir ini adalah kepatuhan perusahaan pada peraturan yang berlaku dan menekankan peran ekonomi perusahaan di dalam pasar. Maksud pedoman ini adalah bahwa perusahaan diharuskan untuk mematuhi segala peraturan yang berlaku pada lingkup operasi perusahaan dan berupaya mengedepankan proses usaha yang efisien dan transparan. Diharapkan perusahaan dalam operasinya tidak melanggar hukum sehingga mampu berkembang sesuai dengan hukum yang berlaku karena usaha perusahaan juga terkait dengan pasar yang transparan dan efisien.

Pedoman rights of shareholder and key ownership function dimaksudkan memberi pedoman terkait hak dari pemegang saham terkait dengan pengambilan keputusan dalam perusahaan. Dalam pedoman ini ditegaskan beberapa pokok mengenai hak pemegang saham yakni hak untuk pencatatan kepemilikan secara aman, hak pemindahan saham kepada pihak lain, hak untuk mendapatkan informasi atau materi yang relevan mengenai perusahaan secara berkala, hak untuk berbicara dan memilih dalam rapat umum pemegang saham, memilih dan memberhentikan dewan direksi, dan hak untuk mendapatkan pembagian dari keuntungan perusahaan.

Panduan berikutnya dari OECD adalah equitable treatment of shareholder. Panduan ini memuat tentang keharusan perlakuan yang sama kepada para pemegang saham termasuk perlindungan kepada pemegang saham minoritas dan perlindungan terhadap pemegang saham asing. Penyamaan perlakuan ini dimaksudkan untuk melindungi pemegang saham minoritas dan atau pemegang saham asing dari kemungkinan penyalahgunaan keadaan yang dilakukan oleh pihak pemegang saham mayoritas atau pemegang saham pengendali. Panduan ini juga mencantumkan larangan bagi tindakan insider trading atau perdagangan orang dalam dan juga keharusan bagi direksi untuk mengumumkan bilamana ada transaksi yang berpotensi mengalami benturan kepentingan.

Pedoman selanjutnya adalah Role of stakeholder in coporate governance. Bagian inilah yang kemudian berkembang menjadi sebuah panduan mengenai hubungan perusahaan dengan pemangku kepentingan yang ada di sekitar perusahaan. Pemangku kepentingan ini mencakup pemangku kepentingan yang ikut serta dalam tata kelola perusahaan dan yang tidak turut serta. Pedoman OECD sendiri tidak secara jelas mendefinisikan siapa saja pemangku kepentingan 
dimaksud, hanya saja dengan penjelasan bahwa ada pemangku kepentingan yang ikut terlibat dalam pengelolaan perusahaan dan ada pemangku kepentingan yang tidak terlibat dalam pengelolaan perusahaan.

Disclosure and Transparency merupakan hal terakhir yang menjadi butir pedoman OECD dalam prinsip tata kelola perusahaan. Disclosure and transparency memuat hal-hal mengenai transparansi perusahaan dalam setiap pengumuman ataupun publikasi mengenai perusahaan. Prinsip ini tidak semata dibatasi untuk perusahaan yang mencatatkan sahamnya di bursa efek atau pasar sekunder, melainkan juga untuk semua jenis perusahaan. Prinsip ini juga mengedepankan penyajian laporan keuangan dengan standar akuntansi yang baku dan memberikan informasi yang benar dalam setiap publikasi perusahaan.

$\begin{array}{lcr}\text { Selain } & \text { prinsip } & \text { yang } \\ \text { dikeluarkan oleh } & \text { OECD } \\ \text { sebagaimana diuraikan } & \text { diatas, } \\ \text { secara umum tata } & \text { kelola }\end{array}$
perusahaan yang baik mengandung empat hal yakni akuntabilitas (accountability) , keterbukaan (transparancy), kewajaran (fairness), dan bertanggung jawab (responsibility) (Jamin Ginting, 2008). Menurut penulis, sepatutnya konsep responsibility diterjemahkan menjadi pertanggung jawaban karena pada penjabarannya lebih jauh yang menjadi titik tekan adalah bagaimana perusahaan mempertanggungjawabkan usahanya, bukan sekedar bertanggung jawab. Menurut Adrian Sutedi, prinsip dasar yang harus diperhatikan dalam corporate governance adalah Transparansi, Dapat dipertanggungjawabkan, kejujuran, dan keberlanjutan.

Dari berbagai konsep umum GCG, kemudian melahirkan relasi antara perusahaan dengan pemangku kepentingan yang ada di sekitarnya. Keberlangsungan perusahaan dan perkembangan masyarakat menjadi hal yang tak terpisahkan. Pada satu sisi Perusahaan sebagai sebuah entitas ekonomi harus berupaya menghasilkan keuntungan sebesarbesarnya dengan tetap mematuhi nilai-nilai tata kelola yang baik, dan pada sisi lain perusahaan juga harus memperhatikan pemangku kepentingan yang ada di sekitarnya dengan memberdayakan mereka.

Pendapat lain dikemukakan oleh laporan Komite Nasional Kebijakan Governance (KNKG) dalam laporannya pada 2006 KNKG mencetuskan lima prinsip tata kelola perusahaan yang baik yakni Transparansi (transparency), Akuntabilitas (Accountability), Responsibilitas (Responsibility), Independensi (independency), Kewajaran dan kesetaraan (Fairness) (Komite Nasional Kebijakan Governance, 2006). KNKG mengintrodusir independensi kedalam sebuah prinsip tersendiri dalam tata kelola perusahaan yang baik.

Menurut rumusan KNKG yang dimaksud dengan asas independensi adalah independensi 
setiap organ perusahaan sehingga organ perusahaan tidak saling mendominasi dan tidak dapat diintervensi pihak lain. Dijabarkan lebih lanjut dalam pedoman pokok pelaksanaan bahwa setiap organ perusahaan dalam melaksanakan tugasnya harus menghindari terjadinya dominasi oleh pihak manapun, tidak terpengaruh kepentingan tertentu, bebas dari benturan kepentingan dan dari segala pengaruh atau tekanan, sehingga pengambilan keputusan dapat dilakukan secara obyektif. Ditegaskan pula bahwa setiap organ perusahaan harus melaksanakan fungsi dan tugasnya sesuai dengan anggaran dasar dan peraturan perundang-undangan tidak saling mendominasi atau melempar tanggung jawab antara satu dengan yang lain.

Dalam hal responsibilitas, KNKG menjabarkan prinsip bahwa perusahaan harus mematuhi peraturan perundang-undangan serta melaksanakan tanggung jawab terhadap masyarakat dan lingkungan sehingga dapat terpelihara kesinambungan usaha dalam jangka panjang dan mendapat pengakuan sebagai good corporate citizen. Dalam hal tanggung jawab sosial, perusahaan harus peduli terhadap masyarakat dan kelestarian lingkungan terutama di sekitar perusahaan dengan membuat perencanaan dan pelaksanaan yang memadai.

Komisi Nasional Kebijakan Corporate Governance menetapkan 13 prinsip tata kelola perusahaan yang baik yang delapan diantaranya meliputi internal balance. Prinsip-prinsip tersebut terkait dengan pemegang saham dan RUPS, Dewan Komisaris dan komite pendukungnya, direksi, sistem audit, sekretaris perusahaan, keterbukaan, kerahasiaan, dan informasi orang dalam. Lima prinsip yang terkait dengan external balance hanya disinggung secara singkat yakni terkait dengan pihak yang berkepentingan, etika berusaha dan antikorupsi, donasi, kepatuhan pada peraturan perundangundangan tentang proteksi kesehatan, keselamatan kerja dan pelestarian lingkungan, dan kesempatan kerja yang sama (Adrian Sutedi, Op cit,41).

Ada beberapa model dalam pelaksanaan tata kelola perusahaan yang baik yakni principal-agent model, myopic market model, dan stakeholder model. Principal-Agent Model menitikberatkan pengelolaan korporasi pada win-win solution antara pemegang saham sebagai pemilik di satu pihak dan manajer sebagai agent di lain sisi. Myopic market model masih memfokuskan perhatian pada kepentingankepentingan pemegang saham dan manajer, dimana sentimen pasar lebih banyak dipengaruhi oleh faktor-faktor lain di luar corporate governance. Model lainnya adalah stakeholder model yang memberikan perhatian kepada seluruh pihak yang terkait dengan korporasi secara luas. Model ini menitikberatkan bahwa dalam mencapai tingkat pengembalian yang menguntungkan bagi pemegang saham, manajer harus 
memperhatikan adanya batasanbatasan yang timbul dalam lingkungan dimana mereka beroperasi, diantaranya masalah etika dan moral, hukum, kebijakan pemerintah, lingkungan hidup, sosial budaya, politik dan ekonomi.

Jika ditelaah dari berbagai rumusan mengenai Good Corporate Governance nampak jelas bahwa suatu perusahaan dapat dikategorikan telah menyelenggarakan tata kelola perusahaan yang baik jika perusahaan tersebut turut bertanggung jawab atau berpartisipasi dalam pengembangan stakeholder khususnya warga masyarakat dan lingkungan yang ada di sekitar tempat operasinya. Secara filosofis maka dapat dikatakan bahwa Tanggung Jawab Sosial Perusahaan adalah tanggungjawab yang lahir bukan karena kewajiban bahwa perusahaan wajib untuk bertanggungjawab pada stakeholder, namun lebih sebagai sebuah kesadaran dalam menjalankan tata kelola perusahaan yang baik.

\section{Social Engineering Tata Kelola Usaha Yang Baik}

Langkah formulasi Tanggung Jawab Sosial dan Lingkungan ke dalam Undang-Undang Nomor 40 Tahun 2007 tentang Perseroan Terbatas, yang diakui oleh Pemerintah dan didorong oleh Fraksi-Fraksi yang ada di DPR menunjukkan bahwa kendatipun Rencana Pembangunan Jangka Menengah 2004-2009 menggunakan
Friedmann, yang membagi hukum menjadi Substansi, Struktur, dan budaya hukum, arah Politik hukum Pemerintahan di Indonesia tak bisa dilepaskan dari pengaruh pendekatan Teori Hukum Pembangunan yang menitikberatkan Hukum sebagai sarana untuk melakukan perubahan sosial.

Hal ini juga menunjukkan perkembangan yang signifikan dalam Hukum Perusahaan di Indonesia. Jika sebelumnya regulasi mengenai Perseroan Terbatas semata-mata hanya tercantum dalam beberapa rumusan pasal dalam Kitab Undang-Undang Hukum Dagang, maka butuh waktu 50 tahun sejak kemerdekaan Indonesia untuk melahirkan Undang-Undang Perseroan Terbatas Nomor 1 Tahun 1995. Undang-Undang Perseroan Terbatas Nomor 1 Tahun 1995 dalam waktu yang demikian cepat dirasa perlu untuk dirubah, yakni hanya dalam jangka waktu 12 tahun saja sejak diundangkannya Undang-Undang Nomor 1 Tahun 1995, UndangUndang Nomor 40 Tahun 2007 diundangkan.

Perkembangan dunia yang begitu pesat dalam periode 19952007 khususnya perkembangan mengenai tumbuhnya kesadaran Tata Kelola Usaha yang baik akibat terjadinya krisis ekonomi, mengantarkan Indonesia pada kebutuhan untuk mereformasi hukum Perseroan terbatasnya.

Keadaan inilah kemudian yang kita bisa tinjau dari pendapat Pemerintah dan Fraksi-Fraksi di 
DPR dalam Pembahasan Rancangan Undang-Undang Perseroan Terbatas yang dengan suara bulat menyetujui penerapan tanggung jawab sosial dan lingkungan dalam formulasi pasal tersendiri. Formulasi tersebut yang secara khusus menggariskan kewajiban baru bagi perseroan, juga diiringi berbagai perubahan yang signifikan dalam hal tata kelola perusahaan mengacu pada prinsip tata kelola usaha yang baik.

Dalam kaitannya dengan Teori Hukum Pembangunan yang mengetengahkan Law as a tool of social engineering, atau Hukum sebagai sarana untuk melakukan perubahan sosial, maka langkah menyerap prinsip-prinsip tata kelola yang baik ke dalam rumusan Undang-Undang Perseroan Terbatas secara umum, dan secara khusus menyiapkan formulasi mengenai Tanggung Jawab Sosial dan Lingkungan dalam formulasi Pasal tersendiri menunjukkan bahwa Pembuat Undang-Undang menggunakan Undang-Undang sebagai sarana untuk mewujudkan Perseroan Terbatas yang menerapkan tata kelola usaha yang baik.

\section{Kesimpulan}

1. Bahwa formulasi Tanggung Jawab Sosial dan Lingkungan dalam Undang-Undang Nomor 40 Tahun 2007 tentang Perseroan Terbatas merupakan salah satu upaya Politik Hukum Pembuat Undang-Undang agar Perseroan Terbatas melaksanakan tata kelola usaha yang baik umumnya dan secara khusus dapat lebih peduli kepada pemangku kepentingan yang ada disekitarnya.

2. Bahwa pendekatan pelaksanaan Tanggung Jawab Sosial dan Lingkungan yang diformulasikan dalam UndangUndang merupakan langkah yang dapat dikategorikan sebagai upaya untuk melakukan "social engineering" atau rekayasa sosial guna mencapai keadaan yang diinginkan yakni Perseroan Terbatas yang menerapkan prinsip tata kelola usaha yang baik dan peduli pada pemangku kepentingan di sekitarnya.

\section{Daftar Pustaka}

\section{Buku}

Atmasasmita, Romli, "Teori Hukum Integratif, Rekonstruksi tentang Teori Hukum Pembangunan dan Teori Hukum Progresif" Genta Publishing; Yogyakarta; 2012. Bruggink , JJ H, "Refleksi Tentang Hukum, Pengertian-pengertan dasar dalam Teori Hukum" Citra Aditya Bakti, Bandung, Cet VII, 2015.

Hartono, C.F.G Sunaryati, "Politik Hukum Menuju Sistem Hukum Nasional" Alumni, Bandung, 1991

Haryanto ,Kolier, dkk, "Politik Hukum Dalam Pembaharuan Undang-Undang Perseroan Terbatas, Pergulatan eksekutif, legislative dan korporat", Indonesia Future Institute, Jakarta, 2007.

Kartini, Dwi. Corporate Social Responsibility Transformasi 


$\begin{array}{lr}\text { Konsep } & \text { Sustainability } \\ \text { Management } & \text { dan } \\ \text { Implementasi di } & \text { Indonesia. } \\ \text { Bandung: Refika } & \text { Aditama, } \\ 2009 . & \end{array}$

Kusumaatmadja ,Mochtar. "KonsepKonsep Hukum dalam Pembangunan (Kumpulan Karya Tulis)", Alumni Bandung. 2006.

Mahfud MD ,Moh. "Politik Hukum Indonesia", Rajawali Press, Jakarta, 2009.

Masriani, Yulies Tina. Pengantar Hukum Indonesia. Jakarta: Sinar Grafika, 2004.

Mertokusumo, Sudikno, "Teori Hukum" ; Universitas Atmajaya Yogyakarta; Yogyakarta, Cet V. 2015.

Rasjidi ,Lili \& Rasjidi , Ira Thania, "Pengantar Filsafat Hukum", Mandar Maju, Bandung.2007

Simorangkir, Theodorik, \& Arifah, Ninuk; Ed. "Pengkajian Hukum Tentang Tanggung Jawab Sosial Perusahaan", Badan Pembinaan Hukum Nasional Departemen Hukum dan Hak Asasi Manusia RI ; Jakarta; 2009.

Surya, Indra and Ivan Yustiavandana. Penerapan Good Corporate Governance Mengesampingkan Hak Istimewa Demi Kelangsungan Usaha. Jakarta: Kencana, 2008.

Sutedi, Adrian. Good Corporate Governance. Jakarta: Sinar Grafika, 2011.

Wibisana , Muhammad Wiman ." Tanggung Jawab Sosial dan

\begin{abstract}
Lingkungan Pada PT Bank Danamon Indonesia ditinjau dari Perspektif UndangUndang Nomor 40 Tahun 2007 tentang Perseroan Terbatas" Tesis, Universitas Gadjah Mada , Yogyakarta 2012
\end{abstract}

\section{Jurnal}

Bismar Nasution, , Vol 22 No 6 tahun 2003. "Prinsip Keterbukaan dalam Good Corporate Governance." Jurnal Hukum Bisnis Volume 22. Edisi 6 (2003).

Jamin Ginting, 2008, Vol III No.2 November 2008."Tinjauan Yuridis terhadap CSR dalam GCG”, Law Review, FH UPH Vol III No.2 November 2008.

\section{Laporan}

Komite Nasional Kebijakan Governance, 2006, Pedoman Umum Good Corporate Governance, KNKG.

Organization for Economic Co-operation and Development , 2004, OECD Principle of Corporate Governance, Organization for Economic Cooperation and Development,

\section{Website}

Milton Friedman. "Colorado University." 13 September 1970. The Social responsibility of Business is to increase the profits. Diakses 30 Juli 2016. $<$ www.colorado.edu/student groups/libertarians/issues friedman-soc-respbusiness.html>. 